\section{Manned mission to Mars}

SIR - The cost of a manned mission to Mars is currently estimated at $\$ 500,000$ million and rising. To this must probably be added the loss of one or more flight crews, a toll that is highly likely in view of the experiences of the Apollo and shuttle programmes. So terribly dear a project requires justification commensurate with its cost, but no such justification has ever been offered, as none exists. There are no scientific grounds for the mission, it being generally agreed that robots can perform scientific tasks in space as well as, or better than, human beings, at far less cost and with no risk to life. In our time, unlike previous centuries, men do not have to be sent to explore the unknown; they can explore through the robots they create and control. A manned mission to Mars is a fifteenth century response to a twentyfirst century problem.

The justifying arguments usually given for a manned mission are political and metaphysical. They include appeals to national pride, assurances that a manned Mars mission will fulfil human destiny and that collaboration with the Soviets in this venture is important for world peace, and other highly dubious claims. Bruce Murray, in his recent 'manifesto' (Nature $\mathbf{3 4 5}$, $199 ; 1990)$ adds vicarious adventure to this list. He thus confirms what some of us have long believed - that public entertainment is one of the real motives for manned spaceflight.

Division of Biology,

California Institute of Technology,

Pasadena, California 91125, USA

SIR-The US president has declared for Mars. The vice-president, head of the National Space Council, has declared, "We have seen pictures [of Mars] where there are canals, we believe, and water. If there is water, that means there is oxygen. If oxygen, that means we can breathe". Sadly, US space policy seems more appropriate for the plot of a B-movie or a 1930s pulp novel than for the energies of a world power. That policy seems to have been developed by Americans unaware of the lessons learned from the exploration of their own continent more than 400 years ago. And that policy ignores a far better goal for off-planet human presence.

Bruce Murray's article ${ }^{\prime}$ advocating USSoviet cooperation on a jaunt to Mars was not misguided. If we are to go, he reasons correctly, we should go together and share the costs. The problem is in the going. While famine, toxic waste and global climatic change are becoming accepted realities here on Earth, it makes little sense to spend the enormous human energy required to throw a handful of human beings out of one massive gravity well only to send them plummeting down into another, onto the surface of a world so bleak that even the sixteenth century British explorer Martin Frobisher would have thought it a frigid and barren hell.

We might learn something from Frobisher's three fruitless expeditions to the New World. From 1576 to 1578 , with both Crown and private backing, Frobisher led hundreds of men to the icy coasts of what is now far-northern Canada ${ }^{2}$. His ships dodged ice floes, his men toiled through July and August snow storms, to bring back 1,350 tons of worthless black rocks, mistakenly thought to contain gold. Those expeditions were such a failure that they may have frightened many British investors away from financing further New World expeditions.

Now President Bush wants to send a few astronauts to Mars so that they can walk around for a bit and come back loaded with rocks. Yet modern North American space policy ignores a far more justifiable goal for human presence in space: trying to make that presence both materially and economically self-sufficient. A trip to Mars would require only an elaboration of existing technologies and an enormous infusion of government money. But a small independent colony, placed wherever it could function best, employing as yet undeveloped biotechnology to recycle wastes and grow its own food, would be an incomparable scientific achievement.

We don't need more rocks here on Earth. We need to find solutions to Earth's environmental problems. Lessons in self-sufficiency, learned by biologists and engineers in a small test-tube colony in space, might provide some of those solutions.

ChARLES A. GARDNER Department of Anatomy and Cell Biology, University of Michigan Medical School, Ann Arbor, Michigan 48109, USA

1. Murray, B. Nature 345, 199-200 (1990).

2. Morison. S.E. The European Discovery of America: The Northern Voyages (Oxford University Press, New York, 1971).

\section{Czech science}

SIR-I wish to add to your account of Czechoslovak science (Nature 344, 607$609 ; 1990)$ two further relevant points.

First, modern science has not only "marvellously . . . survived forty-two years of the old regime" as you say; it developed during Communist rule and is correspondingly biased. Institutes of the Academy of Sciences dealing with basic research (with more than 15,000 employees, in a country with 15 million inhabitants) are almost totally divorced from the universities; scientific productivity is lower than in advanced Western countries; the isolation of the country has been disastrous for science and its economic problems made large-scale science by high-technology instruments impossible; the old regime was able to recruit scientists from the level of institutes up to the presidium of the academy who readily adapted to its requirements and managed - or mismanaged - science on behalf of the Party and Government without taking the personal risk of trying to improve the situation.

Second, not enough is said in your articles about the future. The most important needs now are: (1) to maintain, develop and optimize our actual research base in spite of continued economic and social problem; (2) to increase standards of research and productivity by increasing motivation to reach an international level, by emphasizing democratic principles in structure, management and financing, by sending creative young people (who it is hoped would return) to the best laboratories abroad and by removing all obstacles (including the financial ones) to scientific communication and travelling; and (3) to provide from elsewhere, qualified help (mostly to its badly retarded technology, education, health care and ecology) as well as to contribute to a general improvement of cultural, moral and humanitarian standards.

Although all this requires mainly that we work more and better, solidarity and support from the international scientific community would be of great value. In addition, research grants making possible the acquisition of modern instrumentation, travel, postgraduate training, attendance at conferences and so on, and the publication of good scientific papers by international journals would greatly contribute to European and worldwide integration of Czechoslovak science.

Institute of Physiology,

TOMÁŠ RADIL

Czechoslovak Academy of Sciences,

14220 Prague 4 ,

KRČ, Videňská 1083 ,

Czechoslovakia

\section{European projects}

SIR-In your leading article "Metrication and the falling yen" (Nature 344, 575; 1990 ), you refer to "the Hermes spacecraft" that "will be built in France".

Hermes is a programme of the European Space Agency and the correct statement is that it is built mainly in Europe. My comment is not intended to diminish the role of France but I should like to remind you of the European nature of programmes such as Hermes, Ariane, Airbus and many more.

\section{J. FEUSTEL-BUECHL}

European Space Agency,

8-10 Rue Mario-Nikis,

75738 Paris Cedex 15 ,

France 